\title{
COMPARATIVE EFFICACY EVALUATION OF MOXIDECTIN AND IVERMECTIN INJECTABLE FORMULATION AGAINST HELMINTHES INFESTATION OF DONKEYS (EQUUS ASINUS) IN SUDAN
}

\author{
M.I. FANGAMA*; H.I. SERI ${ }^{* *}$; S.E. SULIMAN**; S.M.A. IMAM ${ }^{* * *}$ and E.A. MOZAMEL ${ }^{*}$ \\ *Ministry of Animal Resources, Elgedarif State, Sudan. \\ ${ }^{* *}$ College of Veterinary Medicine, Sudan University of Science and Technology. \\ ${ }^{* * *}$ Ministry of Animal Resources, South Darfur State, Sudan. \\ hishamseri@sustech.edu
}

ABSTRACT

Received at: $15 / 1 / 2013$

Accepted: 6/3/2013
A total of 24 male and female donkeys of local breed, 4-10 years of age and naturally infected with helminth parasites was utilized in a controlled study to evaluate the efficacy of Moxidectin injectable formulation at the dosage of $0.2 \mathrm{mg} / \mathrm{kg}$ of live weight used either subcutaneously or intramuscularly and an ivermectin injectable formulation at the dosage of $0.2 \mathrm{mg}$ per $\mathrm{Kg}$ applied subcutaneously. Animals were allocated randomly into four groups of six donkeys each, and treatments were randomized among the groups. One group was kept as untreated control. The experiment extended for 14 days. Faecal samples were collected at day 0 (before treatment), and then at 1, 2, 3, 7 and 14 days post treatment. The number of parasites remaining in each animal was determined after necropsy of the animals at day 14 post treatment for all donkeys. Both Moxidectin subcutaneously or intramuscularly and ivermectin administered subcutaneously reduced initial EPG from a mean of 550, 700, and 600 to 50 (90.9\%), 150 (78.5\%), and zero (100\%) at the end of trial on day 14. Efficacy percentages of Moxidectin and ivermectin against immature and adult nematodes were as follows: Trichostrongylus axei, Parascaris equorum. Habronema muscae $100 \%$ for both products; respectively. Cyathostomes spp.; Strongyloides westeri and Oxyuris equi $100 \%$, for the two products. No Gasterophilus larvae were found in donkeys from treated groups, while all the control donkeys had infections with this parasite. Ivermectin showed greater efficacy (99.8\%) than moxidectin (74.4 and 98\%) against Strongylus vulgaris larvae found in the mesenteric artery aneurisms. No adverse reactions were observed during the experimental period.

Keywords: Moxidectin, ivermectin; donkeys, helminthes, Sudan.

\section{INTRODUCTION}

The importance of helminthes infestation in donkeys in Sudan has been documented by the work of several authors (Seri et al., 2004a, Sawsan et al., 2008). Recent reports concerning the treatment of donkeys helminthiasis was demonstrated by the work of Seri et al., (2004b and 2005) and Sawsan et al., (2010) using doramectin, ivermectin and Albendazole, respectively.

Moxidectin is a macrocyclic lactone with structural similarities to ivermectin and milbemycin oxime (Carter et al., 1987; Shoop, 1993). Such similarities suggest that these compounds may share activity towards important parasites of man and animals, while structural differences may impart variations in dosage levels or the spectrum of susceptible parasites, therefore, these compounds warrant evaluation as alternatives to ivermectin treatment.

Many authors have demonstrated the endoectocidal efficacy of Moxidectin in horses harbouring natural infections of nematodes and Gasterophilus larvae (DiPietro et al., 1992; Lyons et al., 1992; Reinemeyer and Tineo, 1993; Bello and Laningham, 1994; Xiao et al., 1994; Cobra et al., 1995; Jacobs et al., 1995; Monahan et al., 1995 and Gulanber et al., 1998).

The present study was designed to compare therapeutic efficacies of injectable formulation of Moxidectin (either injected intramuscularly or subcutaneously), used at dosage of $0.2 \mathrm{mg}$ per $\mathrm{Kg}$ of body weight against larval and adult stages of helminthes in naturally infected donkeys under Sudanese conditions. Also to report on side and/adverse effects, if any. An ivermectin injectable formulation injected subcutaneously at a dose of o. 2 
mg per $\mathrm{Kg}$ was included in the assay for comparative purposes.

\section{MATERIALS and METHODS}

Experimental animals. In this study we utilized 24 male donkeys (3-10 years). Before starting the study, animals were examined to prove infestation with gastrointestinal helminthes. The animals were kept at a private farm located at the periphery of Elgedarif town. They were provided with tap water and allowed to graze freely in pasture.

Experimental drugs. The following drug formulations and trade marks were used as experimental drugs: Moxidectin: Cydectin ${ }^{\circledR}$ injection, Fort Dodge Veterinaria, S.A. (Spain). Ivermectin: kelamectin ${ }^{\circledR}$ $1 \%$ injection, KELA Laboratoria N.V., Sint Lenaartseweg48, B 2320 Hoogstraten, BELGIUM.

Experimental design. The animals were allocated into four groups and penned according to treatment groups. The first three groups were treated and the last group remained untreated as a control group. The animals in the three treatment groups received treatment as follows:

Moxidectin treated group 1 (Mox1) received a single subcutaneous dose of Moxidectin at the manufacturer's recommended dose of $0.2 \mathrm{mg} / \mathrm{kg}$ body weight.

Moxidectin treated group 2 (Mox2) received a single intramuscular dose of Moxidectin at the manufacturer's recommended dose of $0.2 \mathrm{mg} / \mathrm{kg}$ body weight.

Ivermectin treated group (IVMT) received a single subcutaneous dose of ivermectin injectable at the manufacturer's recommended dose of $200 \mu \mathrm{g} / \mathrm{kg}$ body weight.

Then donkeys were monitored for possible adverse or unwanted reactions for 2 hours after administration of each drug.

The experiment was extended for 14 days. Faecal samples were collected at 0 (before treatment), 1, 3, 7, and 14 days post treatment. Necropsy of the animals was done at day 14 post treatment for all donkeys.
Animals were euthanized for worm recovery as described by Reinecke and Le Roux (1972). After the donkeys were euthanized, the thoracic and abdominal cavities were opened by making an incision along the ventral line of the animal and the left half of the thorax and the abdominal wall was removed. The organs from the thoracic and the abdominal cavities were removed from the carcass. The different organs from the gastrointestinal tract were then isolated by tying double ligatures around the gut to separate it in the stomach, small intestine, caecum, colon and rectum. The contents of the different organs were removed and then sieved through a $150 \mathrm{~mm}$ sieve to obtain residue samples. The residues preserved in $10 \%$ formalin. Residue samples of ingesta were examined macroscopically. Nematodes present were placed in a specimen bottle containing $10 \%$ formalin. Helminthes were identified at a later stage by placing them on a glass slide, examining them microscopically and classifying them according to Lichtenfels (1975)

The anthelmintic efficacy of Moxidectin and ivermectin was estimated using a faecal egg count reduction test (FECR) for helminthes burden. The arithmetic mean of the egg count and helminthes burden was calculated to determine the mean percentage reduction within each group, according to the following formula:
$\mathrm{FECR} \%=\underline{\text { Pre-treatment EPG }- \text { Post-treatment EPG }} \times$ 100
Pre-treatment EPG

A modified McMaster technique (Anonymous, 1986) was used to count the egg per gram (epg) of faeces.

\section{RESULTS}

The results of mean egg per gram of faeces and the range in addition to the reduction percentage of egg per gram of faeces for the three treated groups from day zero to day 21 are presented in the Tables 1,2 and 3 .

On day 3, Moxidectin (S/C) showed reduction of $81.8 \%$ egg per gram count (EPGC), while Moxidectin (IM) showed $71.4 \%$. In ivermectin treated group $100 \%$ of egg per gram count (EPGC) was reported. The three groups reported $90.9 \%, 78.5 \%$ and $100 \%$ reduction of egg per gram of faeces on day 14 for Moxidectin (S/C), Moxidectin (IM) and ivermectin respectively. 
$\underline{\text { Assiut Vet. Med. J. Vol. } 59 \text { No. } 137 \text { April } 2013}$

Table 1: Mean faecal egg counts and reduction for moxidectin treated donkeys (subcutaneous injection).

\begin{tabular}{cccc}
\hline Day & Arithmetic Mean (EPG) & Range & Mean Reduction $\%$ \\
\hline 0 & 550 & $300-1500$ & - \\
\hline 1 & 550 & $300-1500$ & 0 \\
\hline 2 & 800 & $300-3600$ & -31.2 \\
\hline 3 & 100 & $0-600$ & 81.8 \\
\hline 7 & 100 & $0-300$ & 81.8 \\
\hline 14 & 50 & $0-300$ & 90.9 \\
\hline
\end{tabular}

Table 2: Mean faecal egg counts and reduction for moxidectin treated donkeys (intramuscular injection).

\begin{tabular}{cccc}
\hline Day & Arithmetic Mean(EPG) & Range & Mean Reduction \% \\
\hline 0 & 700 & $300-900$ & 21.4 \\
\hline 1 & 550 & $300-2400$ & 85.7 \\
\hline 2 & 100 & $0-900$ & 71.4 \\
\hline 3 & 200 & $0-600$ & 100 \\
\hline 7 & 0 & $0-0$ & 78.5 \\
\hline 14 & 150 & $300-600$ &
\end{tabular}

Table 3: Mean faecal egg counts and reduction for ivermectin treated donkeys (subcutaneous injection).

\begin{tabular}{cccc}
\hline Day & Arithmetic Mean(EPG) & Range & Mean Reduction $\%$ \\
\hline 0 & 600 & $300-600$ & 75 \\
\hline 1 & 150 & $0-300$ & 83.3 \\
\hline 2 & 100 & $300-3900$ & 100 \\
\hline 3 & 0 & 0 & 100 \\
\hline 7 & 0 & 0 & 100 \\
\hline 14 & 0 & 0 & 2
\end{tabular}

The results of post-mortem findings are presented in the Tables 4, 5 and 6 for the three groups. Moxidectin administered either subcutaneously or intramuscularly showed efficacy of $100 \%$ and Ivermectin administered subcutaneously also showed $100 \%$, but the efficacy against L4 Strongylus vulgaris found in the cranial mesenteric arteries was $74.4 \%$ for Moxidectin S/C and 98\% for Moxidectin (IM), as shown in tables (4 and 5). On the other hand, ivermectin showed $99.8 \%$ efficacy against L4 Strongylus vulgaris.

Figures (1, 2 and 3) show Gasterophilus larvae, Parascaris equorum, and Strongylus vulgaris larvae, in different parts of GIT and cranial mesenteric artery aneurisms of a donkey in the control group (not treated). 
$\underline{\text { Assiut Vet. Med. J. Vol. } 59 \text { No. } 137 \text { April } 2013}$

Table 4: Summary of worms recovered from control and animals treated with Moxidectin (S/C) at necropsy.

\begin{tabular}{|c|c|c|c|}
\hline \multirow{2}{*}{ Organs examined } & \multirow{2}{*}{ Control } & \multicolumn{2}{|c|}{ Moxidectin Sc } \\
\hline & & No. & Reduction \% \\
\hline \multicolumn{4}{|c|}{ Cranial mesenteric artery } \\
\hline Strongylus vulgaris & 148 & 38 & 74.4 \\
\hline \multicolumn{4}{|l|}{ Stomach } \\
\hline \multicolumn{4}{|l|}{ Gasterophilus spp. } \\
\hline Habronema spp. & 157 & 0 & 100 \\
\hline \multicolumn{4}{|l|}{ Trichostrongylus axei } \\
\hline \multicolumn{4}{|l|}{ Small Intestine } \\
\hline Parascaris equorum & 15 & 0 & 100 \\
\hline \multicolumn{4}{|l|}{ Caecum } \\
\hline Gasterophilus spp. & & & 100 \\
\hline Strongylus spp. & 3315 & 0 & 100 \\
\hline Cyathostomes spp. & & & 100 \\
\hline \multicolumn{4}{|l|}{ Colon } \\
\hline \multicolumn{4}{|l|}{ Strongylus spp. } \\
\hline $\begin{array}{l}\text { Cyathostomes spp. } \\
+ \text { Strongyloides westeri } \\
+ \text { Oxyuris equi }\end{array}$ & 26203 & 0 & 100 \\
\hline
\end{tabular}

Table 5: Summary of worms recovered from control and animals treated with Moxidectin (IM) at necropsy.

\begin{tabular}{|c|c|c|c|}
\hline \multirow{2}{*}{ Organs examined } & \multirow{2}{*}{ Control } & \multicolumn{2}{|c|}{ Moxidectin IM } \\
\hline & & No. & Reduction \% \\
\hline \multicolumn{4}{|c|}{ Cranial mesenteric artery } \\
\hline Strongylus vulgaris & 148 & 3 & 98 \\
\hline \multicolumn{4}{|l|}{ Stomach } \\
\hline \multicolumn{4}{|l|}{ Gasterophilus spp. } \\
\hline Habronema spp. & 157 & 0 & 100 \\
\hline \multicolumn{4}{|l|}{ Trichostrongylus axei } \\
\hline \multicolumn{4}{|l|}{ Small Intestine } \\
\hline Parascaris equorum & 15 & 0 & 100 \\
\hline \multicolumn{4}{|l|}{ Caecum } \\
\hline Gasterophilus spp. & & & 100 \\
\hline Strongylus spp. & 3315 & 0 & 100 \\
\hline Cyathostomes spp. & & & 100 \\
\hline \multicolumn{4}{|l|}{ Colon } \\
\hline \multicolumn{4}{|l|}{ Strongylus spp. } \\
\hline $\begin{array}{l}\text { Cyathostomes spp. } \\
+ \text { Strongyloides westeri } \\
+ \text { Oxyuris equi }\end{array}$ & 26203 & 0 & 100 \\
\hline
\end{tabular}




\section{Assiut Vet. Med. J. Vol. 59 No. 137 April 2013}

Table 6: Summary of worms recovered from control and animals treated with Ivermectin (S/C) at necropsy.

\begin{tabular}{|c|c|c|c|}
\hline \multirow{2}{*}{ Organs examined } & \multirow{2}{*}{ Control } & \multicolumn{2}{|c|}{ Ivermectin $\mathrm{S} / \mathrm{C}$} \\
\hline & & No. & Reduction \% \\
\hline \multicolumn{4}{|c|}{ Cranial mesenteric artery } \\
\hline Strongylus vulgaris & 148 & 1 & 99.4 \\
\hline \multicolumn{4}{|l|}{ Stomach } \\
\hline \multicolumn{4}{|l|}{ Gasterophilus spp. } \\
\hline Habronema spp. & 157 & 0 & 100 \\
\hline \multicolumn{4}{|l|}{ Trichostrongylus axei } \\
\hline \multicolumn{4}{|l|}{ Small Intestine } \\
\hline Parascaris equorum & 15 & 0 & 100 \\
\hline \multicolumn{4}{|l|}{ Caecum } \\
\hline Gasterophilus spp. & & & 100 \\
\hline Strongylus spp. & 3315 & 0 & 100 \\
\hline Cyathostomes spp. & & & 100 \\
\hline \multicolumn{4}{|l|}{ Colon } \\
\hline \multicolumn{4}{|l|}{ Strongylus spp. } \\
\hline $\begin{array}{l}\text { Cyathostomes spp. } \\
+ \text { Strongyloides westeri } \\
+ \text { Oxyuris equi }\end{array}$ & 26203 & 0 & 100 \\
\hline
\end{tabular}

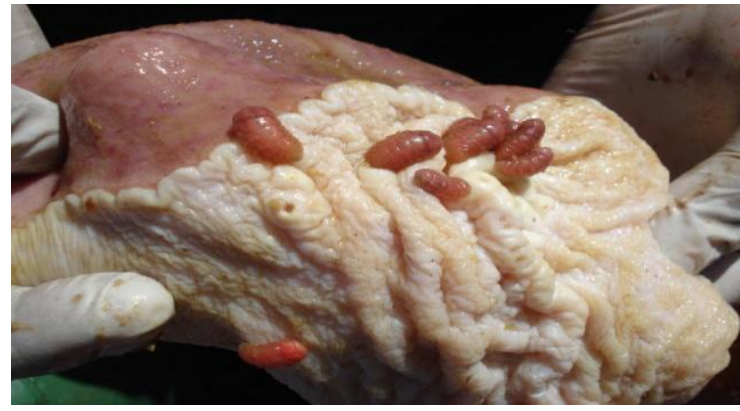

Figure 1: Gasterophilus larvae in the stomach of a non treated donkey

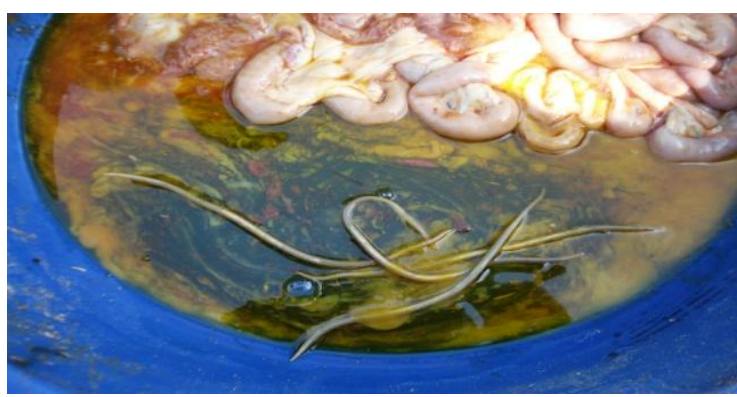

Figure 2: Parascaris equorum removed from intestine of a non treated donkey

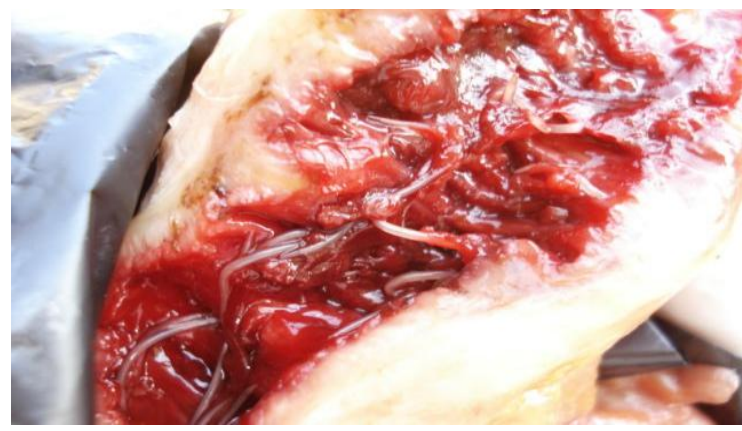

Figure 3: Larvae of Strongylus vulgaris in cranial mesenteric artery removed from control (non treated) donkey 


\section{DISCUSSION}

The first MOX-containing product was an injectable formulation for cattle, approved for commercial use in Argentina in 1989. Subsequent formulations introduced worldwide for control of parasitosis include a tablet and a sustained release injectable for prevention of heartworm disease in dogs, injectable and oral drenches for sheep, a pour-on formulation for cattle and deer, and sustained release injectable formulations for cattle and sheep. These long-acting formulations provided significantly longer persistent activity than the earlier formulations, including season-long control against some parasite species.

For horses, MOX is formulated as unique, easy-to administer oral gel formulation that provides excellent and long-lasting efficacy against nematodes and gastrointestinal bots. A second gel formulation containing $\mathrm{MOX}$ in combination with praziquantel adds efficacy against cestodes.

Horse strongylids are known to be resistant to Benzimidazoles (BZ) and tetrahydropyrimidines (Kaplan 2002, 2004), while the only case of resistance in cyathostomins to macrocyclic lactones was reported in a donkey in the UK (Trawford et al., 2005).

The therapeutic efficacy of Moxidectin in donkeys in this study, in both groups of animals treated either subcutaneously or intramuscularly, was 81.8 and $100 \%$ reduction in (epg) count on day 7 post treatment. Gulanber et al., (1998) obtained a similar result to that of intramuscular injection $(100 \%)$ at day 7 post treatment in horses treated with Moxidectin injectable formulation administered orally. Following post-mortem, Moxidectin administered subcutaneously or intramuscularly resulted in high efficacy of $100 \%$ against Habronema sp., Trichostrongylus axei, Strongyloides westeri\%; Parascaris equorum \%; Strongylus sp.; and Cyathostomum. This result is in accordance to that of Lyons et al. (1992); French et al. (1992); DiPietro et al. (1993); Bello and Laningham (1994); Xiao et al. (1994); Monahan et al. (1995), Scholl (1997); Costa et al. (1998) and Dorchies et al. (1998).

Besides the strongylid nematodes, eggs of Parascaris equorum, Oxyuris equi, Strongyloides westeri and Habronema sp. were found in faecal samples a day before treatment. No eggs of these nematodes were found in horse faeces on the 10th and 14th days after treatment with both drugs.

In this study, ivermectin showed $100 \%$ faecal egg count reduction on day 7, which is in agreement with Seri et al. (2005) and Sawsan et al. (2010), who reported the same result when using ivermectin injectable formulation intramuscularly or subcutaneously, at a dose rate of $200 \mu \mathrm{g} / \mathrm{kg}$ body weight in donkeys in the Sudan, while DiPietro et al. (1982) revealed $100 \%$ efficacy.

When ivermectin was given intramuscularly to donkeys at a dose rate of $200 \mu \mathrm{g} / \mathrm{kg}$, the efficacy was $100 \%$ against larvae of Gasterophilus sp. (Seri et al., 2005), and this result is in agreement with the results obtained in this study. Ivermectin successfully (100\%) removed P. equorum from the small intestine when given orally as a paste formulation at 200 $\mu \mathrm{g} / \mathrm{kg}$. Ivermectin totally eliminated the passage of $P$. equorum in the naturally infected horses (Cobra et al., 1986). In the case of T. axei, ivermectin (100\%) eliminated T. axei from the small intestine of donkeys when used at dose rate of $200 \mu \mathrm{g} / \mathrm{kg}$ in intramuscular formulation (Seri et al., 2005).

In this study, Moxidectin expressed moderate to excellent efficacy of 74.4 to $98 \%$ against Strongylus vulgaris larvae which were found in the cranial mesenteric arteries following subcutaneous and intramuscular injection, respectively. Ivermectin showed efficacy of $99.4 \%$ for the $S$. vulgaris larvae. This result is to be considered to be higher than that reported by Costa et al. (1998) and Seri et al. (2005) who reported $67.8 \%, 69.23 \%$ respectively.

No adverse reactions were observed within the 14 days experimental period, a result which is in line with that reported by Costa et al. (1998).

\section{CONCLUSION}

Although it is recommended to be used as oral gel, Moxidectin injected either subcutaneously or intramuscularly at $0.2 \mathrm{mg} / \mathrm{kg}$ was moderately effective against naturally acquired infections of adult Cyathostomum sp., Strongylus sp., Trichostrongylus axei, Parascaris equorum, Oxyuris equi and Strongyloides westeri gastrointestinal nematodes in donkeys.

These findings suggest that further research might be warranted into the use of new dosage regimens of Moxidectin with higher doses as an equine anthelmintic and to control Strongylus vulgaris in the cranial mesenteric artery.

\section{REFERENCES}

Anonymous (1986): Manual of Veterinary Parasitological Techniques. Ministry of Agriculture, Fisheries and Food. Reference Book 418, (3rd Ed). HMSO, p. 160.

Bello, T.R. and Laningham, J.E.T. (1994): A controlled trial evaluation of three oral dosages of moxidectin against equine parasites. J. Eq. Vet. Sci. 14(9): 483-488. 
Carter, G.T.; Nietsche, J.A. and Borders, D.B. (1987): Structure determination of LL-F28249 alpha, beta, gamma and lamda, potent antiparasitic macrolides from Streptomyces cyanogriseus spp. Noncyanogenus. J. Chem. Soc. Chem. Commun. 6: 402-404.

Cobra, J.; Andrasko, H.; Stoffa, P. and Holakovsky, P. (1986): Efficacy of Eqvalan $^{\mathrm{TM}}$ and Panacur $^{\mathrm{TM}}$ against gastrointestinal nematodes of horses. Veterinary 36, 79-80 (in Slovak).

Cobra, J.; Praslicka, J.; Varady, M.; Tomoasovicova, O.; Andrasko, H.; Holakovsky, P. and Gasparisk, G. (1995): Efficacy of moxidectin (Cydectin, Cyanamid) against some endoparasites ectoparasites of sheep and horses. Slovensky Veterinarsky Casopis 20: 143-147.

Costa, A.J.; Barbosa, O.F.; Moraes, F.R.; Acuna, A.H.; Rocha, U.F.; Soares, V.E.; Paullilo, A.C. and Sanches, A. (1998): Comparative efficacy evaluation of Moxidectin gel and Ivermectin paste against internal parasites of equine in Brazil. Vet. Parasitol. 80: 29-36.

DiPietro, J.A.; Todd, K.S.; Lock, T.F. and McPherron, T.A. (1982): Anthelmintic efficacy of Ivermectin given intramuscularly in horses. Am. J. Vet. Res. 43: 145-148.

DiPietro, J.A.; Paul, A.J.; Ewert, K.M.; Todd, K.S. Jr.; Lock, T.F. and Aguillar, R. (1992): Efficacy of Moxidectin gel in equids, In: Proc. $37^{\text {th }}$ Ann. Meeting, Am. Assoc. Vet. Parasitol. 2-4 August 1992, Boston, MA, p. 51.

Dorchies, P.; Ducos de Lahitte, J.; Flochlay, A. and Blond-Riou, F. (1998): Efficacy of Moxidectin $2 \%$ equine gel against natural nematode infections in ponies. Vet. Parasitol. 74: 85-89.

French, D.D.; Klei, T.R.; Taylor, H.W.; Chapman, M.R.; Monahan, C. and Aguilar, R. (1992): Efficacy of Moxidectin gel against internal parasites of ponies, Proc., $37^{\text {th }}$ Ann. Meeting, Am. Assoc. Vet. Parasitol., 2-4 August 1992, Boston, MA, p. 51.

Gulanber, A.; Tuzer, E.; Gargili, A.; Toparlak, M.; EFIL, I.; Keles, V. and Ulutas, M. (1998): Efficacy of Moxidectin against strongylin nematodes in naturally infected Horses. Tr. J. Vet. Anim. Sc. 22: 465-466.

Jacobs, D.E.; Hutchinson, M.J.; Parker, L. and Gibbons, L.M. (1995): Equine cyathostome infection suppression of faecal egg output with moxidectin. Vet. Rec. 137(21), 545.

Kaplan, R.M. (2002): Anthelmintic resistance in nematodes of horses. Vet. Res. 33: 491-507.

Kaplan, R.M. (2004): Drug resistance in nematodes of veterinary importance. Trends Parasitol. 20: 477-481.

Lichtenfels, J.R. (1975): Helminths of domestic equids. Proc. Helminthol. Soc. Washington. Special issue 42, P. 92.
Lyons, E.T.; Tolliver, S.C.; Drudge, J.H.; Granstrom, D.E.; Collins, S.S. and Stamper, S. (1992): Critical and controlled tests of activity of moxidectin (CL 301423) against natural infections of internal parasites of equids. Vet. Parasitol. 41: 255-284.

Monahan, C.M.; Chapman, M.R.; French, D.D.; Taylor, H.W.; Klei, T.R. (1995): Dose titration of moxidectin oral gel against gastrointestinal parasites of ponies. Vet. Parasitol. 59: 241-248.

Reinecke, R.K. and Le Roux, D.J. (1972): Anthelmintic activity of menbendazole in Equine. J. Vet. Med. Assoc. 43: 287-294.

Reinemeyer, C.R.; and Tineo, A.A. (1993): Comparison of the efficacies of moxidectin gel and ivermectin paste against nematode parasites of horses. Proc. $38^{\text {th }}$ Ann. Meeting, Am. Assoc. Vet. Parasitol., 17-20 July 1993, Minneapolis, MN, p. 32.

Sawsan, M.A. Imam; Seri, H.I.; Hassan, T.; Tigani, T.A.; Hidaia B. Zolain and Abakar, A.D. (2010): Therapeutic efficacy evaluation of anthelmintics activity of albendazole and Ivermectin drench formulations in donkeys in Darfur, Sudan. Vet. Arhiv 80 (5): 585-595.

Sawsan, M.A. Imam; Hassan, T.; Seri, H.I. and Hidaia B. Zolain (2008): Field investigation of gastro-intestinal nematodes in horses and donkeys in South Darfur State, Sudan. $13^{\text {th }}$ scientific congress. Faculty of Veterinary Medicine. Assiut University. Egypt.23-25 November 2008. 723-729.

Scholl, P.J. (1997): The spectrum of activity of Moxidectin 2\% equine gel against internal parasites of horses and ponies. Proc. World Assoc. Ad. Vet. Parasitol., 10-15 August 1997, Sun City, South Africa, pp. 15-19.

Seri, H.I.; Ismail, A.A.; Abakar, A.D. and Tigani, T.A. (2005): Efficacy of ivermectin in an injectable formulation against gastrointestinal nematodes of donkeys (Equus asinus).Vet. arhiv 75: 369-374.

Seri, H.I.; Hassan, T.; Salih, M.M. and Abakar, A.D. (2004a): A survey of gastrointestinal nematodes in donkeys (Equus asinus) in Khartoum State, Sudan. Journal of Animal and Veterinary Advances. 3 (11): 736-739.

Seri, H.I.; Hassan, T.; Salih, M.M.; Abakar, A.D.; Ismail, A.A. and Tigani, T.A. (2004b): Therapeutic efficacy of doramectin Injectable against gastrointestinal nematodes in donkeys (Equus asinus) in Khartoum State of Sudan. Journal of Animal and Veterinary Advances. 3 (11): 726-729.

Shoop, W.L. (1993): Ivermectin resistance. Parasitol. Today, 9: 154-159.

Trawford, A.F.; Burden, F. and Hodgkinson, J.E. (2005): Suspected moxidectin resistance in cyathostomin in two donkey herds at the donkey sanctuary. UK. In: Proceedings of the 
$20^{\text {th }}$ International Conference of the World Association for the Advancement of Veterinary Parasitology, Christchurch, New Zealand, 16-20 October 2005, p. 196.
Xiao, L.; Herd, R.P. and Majewski, G.A. (1994): Comparative efficacy of moxidectin and ivermectin against hypobiotic and encysted cyathostomes and other equine parasites. Vet. Parasitol. 53: 83-90.

\footnotetext{
مقارنة الفعالية الدوائية لعقاري الموكسيديكتين والايفرمكتين عن طريق الحقن ضد الاصابة بالديدان في الحمير في السودان

محمد اسعاعيل فنقاما ، هشام اسعاعيل سري ، سهام الياس سليعان ، سوسن محد أحمد /مام ، /بمان عبد الوهاب مزمل

تم استخدام 24 من الحمير (ذكور و اناث) من السلالة المحلية، تتر او اح اعمار ها بين 4-10 سنوات، و المصابين بشكل طبيعي بالديدان الطفيلية

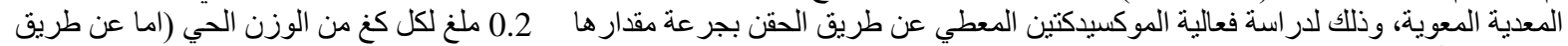

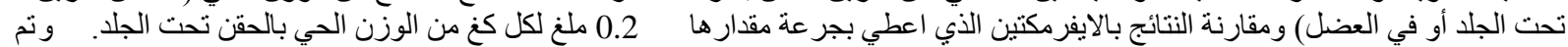

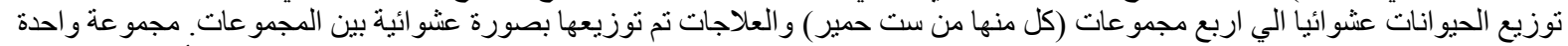

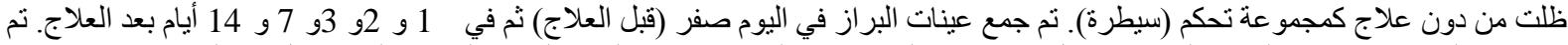

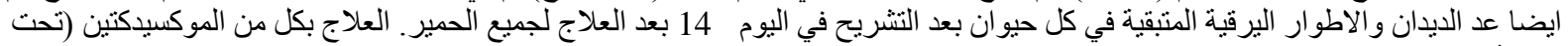

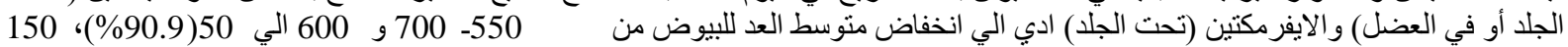

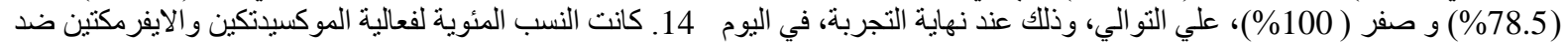

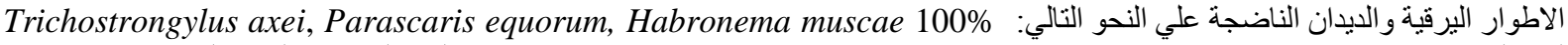

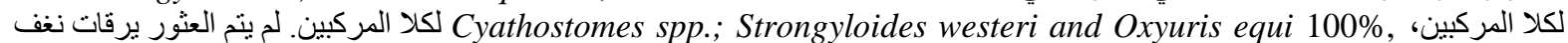

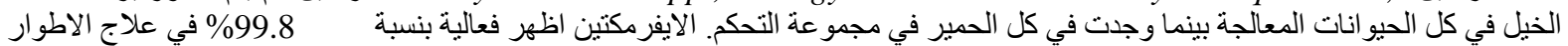

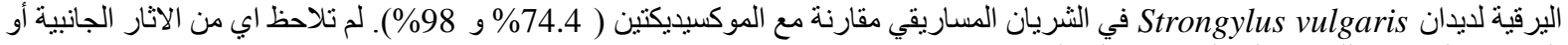
العلامات الظاهرية للتسمم علي الحيو انات المعالجة.
} 